\title{
Prevenção de erros no ensino da leitura
}

\author{
Geraldina Porto Witter ${ }^{1}$ \\ Universidade Camilo Castelo Branco, São Paulo-SP, Brasil
}

Burkins, J. M., \& Groft. M. M. (2010). Preventing misguided reading: New strategies for guided reading teacher. Newark, DE: IRA.

A produção sobre leitura é notável, o livro resenhado traz uma contribuição para a prática sustentada na vivência profissional e no conhecimento científico. Jan M. Burkins é mestre e doutora, professora universitária e trabalha com formação e assessoria a tutores de leitores infanto-juvenis. Melody M. Croft tem mais de 30 anos de vivência profissional, é especialista em recuperação de pessoas com problemas de leitura e mestre na área.

A Apresentação do livro foi feita por Opitz e Ford, conhecidos produtores na área, que enaltecem as possibilidades de não cometer erros usando estratégias que os evitem. Consideram um texto útil para os professores "repensarem, reconsiderarem e renovarem seus esforços para ajudarem todas as crianças a se tornarem leitores proficientes” (p. XI, tradução livre da autora). Posteriormente, é descrito rapidamente o comportamento estratégico de uma professora que serve de apoio ao que se segue. Esta estratégia é usada nos demais capítulos como ponto de partida.

No longo prefácio, as autoras fazem uma síntese do livro resultante de orientações vivenciadas no trabalho com professores. Esclarecem que escreveram a obra em decorrência de terem testado por décadas as estratégias sugeridas e que se mostraram úteis para evitar erros dos professores no processo de ensino-aprendizagem. Também esclarecem que a ordem de apresentação e organização das estratégias no livro é por sua ligação lógica e não por questão de prioridade ou importância. Tratam da problemática dos teóricos não se aplicarem, ou não serem adequadamente aplicadas, na realidade da sala de aula; da desnecessária complexidade das propostas teóricas, as influências do comércio e dos guias padronizados, das pressões para que os alunos estejam na série correspondente a sua idade cronológica, da natureza humana e outros aspectos relacionados com as estratégias propostas.

\footnotetext{
${ }^{1}$ Endereço para correspondência:

Geraldina Porto Witter. Av. Pedroso de Moraes, 144, apto 302. Pinheiros. CEP 05.420-000. São Paulo-SP, Brasil. E-mail: gwitter@uol.com.br
}

A Introdução apresenta as características básicas da proposta de modelo que fazem para a orientação da leitura, comparando-a com o que é tradicionalmente usado. As comparações enfocam como o texto é introduzido, o que os alunos são orientados a fazer, o ponto principal do ensino e o nível de instrução pretendido.

O primeiro capítulo trata da reestruturação do desenvolvimento gradual da responsabilidade que requer que o professor aos poucos vá retirando o apoio dado ao aluno, sendo útil recorrer à leitura em voz alta como forma de iniciar o trabalho, partilhar responsabilidade na leitura em grupo, seguir instruções até ser um leitor independente. São descritas como complemento quatro estratégias: relacionando aprender a ler com contexto educacional, orientações mais como sessão do que lição, estabelecimento de rotinas para o aluno assumir controle e leitura em grupo, com respeito às necessidades do indivíduo e de todos. No final deste e dos demais capítulos, descrevendo estratégias, o leitor encontra questões para orientar o pensar e o conversar sobre a matéria constante no capítulo.

O segundo capítulo trata dos níveis de ensino de leitura em que apresentam uma rápida perspectiva histórica, os mitos existentes, as dificuldades conceituais e de definição de níveis. São apresentadas quatro estratégias: indicar aos alunos livros com os quais possam praticar, trabalhar a sensitividade para que o aluno seja um leitor sem estresse, seleção de material de acordo com o progresso do aluno e esclarecimento de confusões quando o esforço para resolver o problema de leitura se mostra improdutivo. Há dicas para integração das propostas.

No terceiro capítulo, os gradientes de dificuldades do texto são reconsiderados, e apontadas as dificuldades para fazer isto com base científica aceitável, lembram ainda o controle de vocábulo dos textos como problema. São apresentadas seis sugestões de estratégias: ampliando as fronteiras da classificação, emprego de agrupamento flexível, estabelecimento de tarefas com alvos definidos para os leitores independentes. Também enfocam como integrar as estratégias e como orientar os pais.

O quarto capítulo enfoca a instrução equilibrada, lembrando que para ir além, primeiro o leitor iniciante precisa aprender a olhar intimamente as palavras, compreender o que 
elas realmente dizem para ir aprendendo outras sequências de aprendizagem e tudo o que está envolvido nos textos e sua leitura. Seguem três estratégias: envolvimento de todos os alunos a despeito dos níveis de leitura serem diferentes no processo de pensar o texto lido, ensiná-los a ler as ilustrações e encorajá-los a falar sobre o que pensam sem exageros. São dadas pistas de como integrar estas estratégias.

No capítulo seguinte, o tema enfocado diz respeito à retomada do processamento integrando as várias possibilidades de uso das estratégias considerando a leitura como um processo global e que contribui para toda a educação do aluno para que se estabeleça um equilíbrio nas estratégias. Para tanto, são oferecidas cinco estratégias: ensinar o aluno a notar as formas pelas quais o texto lhe pode ser útil, considerar a eficácia de cada aluno no uso da autocorreção, ajudar o estudante a romper com hábitos ineficientes de leitura e fornecer práticas modificadas.

O último capítulo trata do redesenho da avaliação do ato de ler. Partem da perspectiva de que as avaliações padronizadas não viabilizam uma análise qualitativa dos progressos e dificuldades de uma dada criança, bem como, da necessidade de escapar das pressões por nota. Foram lembradas as confusões e misturas nas formas de avaliação, que nem sempre contribuem para o alvo pretendido. Para evitar interpretações errôneas são apresentadas as definições adotadas em seu trabalho. São definidas: Inventários Informais de Leitura, Registros Contínuos e Avaliações Comerciais. A proposta é usar uma síntese para se chegar ao desejado. As sugestões de estratégias são: sair do sistema tudo ou nada, analisar a compreensão como um todo, usar a fluência para ajudar a determinar o nível de leitura instrucional, considerar as formas pelas quais os estudantes integram as pistas textuais, observar as mudanças que o estudante faz no processo de leitura face às dificuldades de compreensão do material. Apresentam uma escala de avaliação para reconhecimento de palavras, compreensão e fluência. Fazem recomendações para uso integrado das estratégias.

No epílogo, manifestam a esperança de que o livro possa ser útil no esforço de formação de leitores. Certamente, muitas das estratégias poderão ser úteis. Na realidade brasileira, precisam ser testadas as propostas levando em conta também a formação dos professores. Como apêndice, aparecem fichas de registro para avaliação continuada e avaliação dos alunos quanto à compreensão do texto (em escala de 1 a 5), reconhecimento de palavras (em porcentagem) e fluência (escala de 1 a 4), com autorização para reprodução de cópias para uso em sala de aula.

As referências datam, em sua maioria, o presente século, com predomínio de livros. O texto é de leitura fácil e prática. Todavia, as autoras poderiam ter elaborado melhor as partes finais dos capítulos, ou seja, explicitar com maior profundidade e exemplificar o item sobre fusão das estratégias. É um texto prático, atual e útil a professores e pesquisadores da área de leitura.
Geraldina Porto Witter é coordenadora geral da Pós-graduação Stricto Sensu da Universidade Camilo Castelo Branco.

Recebido: 03/12/10

$1^{a}$ revisão: 07/02/11

Aceite final: 09/02/11 